Journal of Research in Technical Careers

December 2019, Vol. 3, No. 2.

(C) Author(s)

\title{
The Flipped Classroom and its Impact on Student Engagement and Academic Performance in a Culinary Arts, Career and Technical Education Program
}

\author{
Michael Holik \\ West Chester University
}

\begin{abstract}
The purpose of this study was to gather evidence from a CTE culinary arts program to determine if students perform better academically and are more engaged in the flipped classroom using digital technology, than a traditional classroom. The study included 24 participants in a postsecondary, CTE culinary arts program who were divided into two groups of 12: a traditional, teacher-centered group and a flipped, student-centered group. Utilizing action-based research design, surveys, journals, and an engagement matrix were created and used. Although not statistically significant, student grades in the flipped classroom were nearly $4 \%$ higher than those in the traditional classroom and were consistently higher throughout the semester. This study helps establish a foundation of evidence that student engagement and academic success improve in the flipped classroom for culinary arts CTE students.
\end{abstract}

Keywords: flipped, engagement, student-centered, teacher-centered, learning

\section{Introduction}

Multiple studies involving the use of flipped learning at the postsecondary level exist, focusing on various subjects such as chemistry, medical, mathematics, and engineering (Carter, Carter, \& Foss, 2018; Castedo, Lopen, Chiquito, Navarro, Cabrera, \& Ortega, 2019; Lewis, Chen, \& Relan, 2018; \& Ryan \& Red, 2016). There is little literature regarding the use of flipped learning in career and technical education (CTE) programs, such as. Because of this void, it is difficult to determine if flipped learning would be an appropriate teaching modality for such technical programs. Many teachers are using different strategies to increase student engagement and learning by embracing the use of global technological advancements (Pellas, 2017). Advancements with internet access, mobile technology, and web-based media sources have helped enhance learning both inside and outside the classroom, creating a learning environment suitable for any learning style (Pellas, 2017). Additionally, these technological advancements have made it possible for teachers to flip their classrooms (Fickes, 2014; Foster \& Stagl, 2018). Further, the use of digital technologies in school and other aspects of society today have made it easier for 
Journal of Research in Technical Careers

students to comprehend concepts taught in the classroom (Burgoyne \& Eaton, 2018; Tucker, 2013).

In a typical flipped classroom, students learn the lecture material prior to class through short, digital lessons outside the classroom and spend their time in class actively engaged in meaningful, hands-on application of the material (Burgoyne \& Eaton, 2018; Talbert, 2012). The flipped learning modality is one method of instruction, which can, if designed correctly, change a traditional classroom from teacher-centered to studentcentered (Bergmann \& Sams, 2014; Sezer, 2017). Jukes, McCain, Crockett, and Prensky (2010) and Sezer (2017) state that to engage current generation students, the gap between traditional, teacher-led classrooms and the age of the digital classroom must be closed. In agreement, DeGennaro (2008) notes that a large part of student learning comes from social interactions, many of which incorporate the use of the technology. Being able to reach students through the technology they use on a daily basis may actually create higher levels of student engagement (Foster \& Stagl, 2018; Jukes et al., 2010).

Bringing technology devices students rely on for social reasons into the classroom may also increase student participation and achievement (DeGennaro, 2008; Pellas, 2017). Jukes et al. (2010) and Sezer (2017) note the importance of adapting classrooms to meet the learning needs of modern-day students rather than continuing to teach to the needs of students of generations past. Just as student learning evolves over time, the classroom needs to evolve by incorporating technology (Burgoyne \& Eaton, 2018; Jukes et al., 2010). By incorporating technology, teachers are able to flip the traditional lecture style classroom upside down and administer lectures digitally outside of class and thereby create an active and engaging student-centered learning environment during class (Ng, 2014; Pellas, 2017). According to Ullman (2013), a misconception exists in regard to flipped learning, that it is uniform in delivery no matter the subject; however, there is not a one-size fits all format for all subjects taught (Ullman, 2013).

The purpose of this study was to gather evidence from a CTE culinary arts program to determine if students perform better academically and are more engaged in the flipped classroom than the traditional classroom. Data from this study may provide information allowing instructors to determine whether to proceed with flipped learning or continue utilizing the traditional teaching modality. This study was guided by the following research questions:

1. How does the level of engagement differ for students in a traditional culinary arts CTE classroom, as compared to students in a flipped culinary arts CTE classroom? 2. What differences exist, if any, in student academic performance in a traditional culinary arts CTE classroom, as compared to students in a flipped culinary arts CTE classroom?

\section{Literature Review}

Foundation of the Flipped Classroom. Estes, Ingram, and Liu (2014) claim the importance of understanding that flipped learning is different than a flipped classroom; however, both components are involved with the flipped teaching modality. The flipped classroom targets the physical arrangement of the student education setting, while flipped 
learning encompasses the framework and process of learning in which students engage while in the flipped classroom (Estes et al., 2014). Charged with the task to create a common definition for the flipped classroom, Talbert (2012) organized a group of educators to complete the task. MacKinnon (2015) reports educators discussed components of a flipped classroom and arrived at the definition as a:

. . . pedagogical approach, in which direct instruction moves from the group learning space to the individual learning space, and the resulting group space is transformed into a dynamic, interactive learning environment where the educator guides students as they apply concepts and engage creatively in the subject matter. (p. 45)

Tune, Sturek, and Basile (2013) describe the flipped classroom as students being exposed to lecture material independently through a pre-recorded format such as videos, podcasts, and webinars that are, as noted previously, assigned to watch outside class time. Upon completion of the pre-recorded lessons, students are engaged in a deeper level of thinking and problem-solving in the classroom (Lo, 2018; Love, Hodge, Grandgenett, \& Swift, 2014; Tune et al., 2013). Student-teacher engagement in the classroom gives the teacher the ability to assess students' knowledge and determine their level of comprehension and understanding of the previewed material (Lo, 2018; Tune et al., 2013). Enfield (2013) agrees with Lo (2018) and Tune et al. (2013) and add that during class time, the students are engaged in collaborative work, which is facilitated and monitored regularly by the teacher.

According to Kim, Kim, Khera, and Getman (2014) and Fulton (2012a), flipped learning transforms the traditional teacher-centered learning environment into a studentcentered learning environment, which creates more of an individualized learning opportunity for the students. Stephen Leacock (1922) notes the difference between teacher and student-centered classrooms when he made the following analogy:

If I were founding a university I would found first a smoking room; then when I had a little more money in hand I would found a dormitory; then after that, or more probably with it, a decent reading room and a library. After that, if I still had more money that I couldn't use, I would hire a professor and get some textbooks. (p. 339)

This quote metaphorically symbolizes how the traditional, teacher-centered classroom works, where the teacher directs all details and usually tells too much (Lujan \& DiCarlo, 2014). In the student-centered classroom, the teacher no longer does all the telling, and the students participate in a deeper level of critical thinking, discussions, and searching for solutions on their own, or in groups (Lo, 2018; Lujan \& DiCarlo, 2014).

Benefits of the Flipped Classroom. When the flipped classroom is correctly implemented, the efficient use of time is cultivated for the teachers and students (Kovach, 2014). Continuing this cultivated efficiency outside the classroom, Brunsell and Horejsi (2013) note that students are enjoying the ability to "take their teachers home" through the mode of the digital lessons (p. 8). The flipped classroom can also be an effective way to benefit many types of learners, including students with learning disabilities (McCrea, 
2014). For instance, by requiring components outside the classroom, teachers have more time to work with students individually, so students with learning disabilities are less likely to get behind in their studies (McCrea, 2014). According to Goodwin and Miller (2013), Lo (2018), and Enfield (2013), students are able to increase academic performance and learn at their own pace since the digital lessons are able to be started, stopped, and repeated as many times as needed to gain full comprehension of the material.

Cargile and Harkness (2015) found that the ability for students to review digital lessons in the privacy of their homes as many times as they need would reduce the amount of self-consciousness around peers. In addition to the control over how the students view the lessons, Bergmann and Sams (2013) note that the instruction modules can be watched from anywhere, at any time, and are easy to store and retrieve at a later time. Herreid and Schiller (2013), along with Bergmann and Sams (2012), report that students with busy schedules in school organizations or athletics and work are able to access lessons in the event of missed school for activities, work, or illness.

Kern (2013), Brunsell and Horejsi (2013), and Hutchings and Quinney (2015) state that the flipped classroom format offers more time for hands-on application time and higher quality discussions than was available before in the traditional classroom. Hutchings and Quinney (2015) and Tune et al. (2013) also report that students in a flipped classroom are more accountable for their own learning inside and outside the classroom, and teachers are seeing transformative moments in student learning. Additionally, students enjoy having the academic freedom to manage their education with an indirect benefit of increasing selfgovernance and enthusiasm for learning (Evseeva \& Solozhenko, 2015). Flumerfelt and Green (2013) mentioned the flipped classroom promotes an environment where students can peer teach, which encourages a higher level of personal fulfillment for students. Higher rates of comprehension and understanding of the course content find students learning and developing teamwork skills, whereby in-class discussions create more effective student learning environments (Brunsell \& Horejsi, 2013).

In addition to accountability and personal fulfillment, Gullen and Zimmerman (2013) and Love et al. (2014) note that students enjoy getting their questions answered while working on their assignments right away rather than waiting until the next day. Herreid and Schiller (2013) state that in the traditional classroom, students would work on their homework outside of class. If the students had questions, they would not be able to get the answers they needed right away, and get frustrated, which could lead to higher amounts of incomplete work (Herreid \& Schiller, 2013). According to Hutchings and Quinney (2015), teachers have commented they enjoy how the flipped classroom lengthens instructional time.

Challenges and Misconceptions. Bergman and Sams (2014) and Talbert (2012) emphasize the importance of underlining the potential negatives as well as the benefits of the flipped classroom. Concerns with overuse of technology and how much time students already spend utilizing computers and handheld mobile devices are important (Bergmann \& Sams, 2014; Leung, Kumta, Jin, \& Yung, 2014; Talbert, 2012). Students have stated that taking multiple flipped classes would increase the amount of time engaged digitally both for learning and social reasons (Fulton, 2012b; Lo, 2018). 
Bergmann and Sams (2012) note many people are misinformed about the flipped classroom, thinking it is a one-size-fits all format, and class time is used to sit in front of a computer and learn entirely online. Bergmann, Overmyer, and Wilie (2013) add most misconceptions about flipped classroom modality center around the emphasis placed on watching digital lessons with no other instruction from the teacher, as in an online course. Realistically, computer usage for digital lessons are only one part of the flipped classroom and quality interaction and one-to-one time students get with the teacher in class is the other (Bergmann et al., 2013).

In addition to misconceptions about the flipped classroom, students expressed challenges. Some students did not enjoy taking a learning quiz at the beginning of the period without having time to seek answers to the questions they developed before the session (Tune et al., 2013). Tune et al. (2013) noted that students in the flipped classroom felt as though their workload had increased slightly. Specifically, their study time doubled due to the amount of digital lessons they had to watch prior to attending class (Tune et al., 2013). Enfield (2013) also expresses concerns with the potential for less homework and more time involvement, with less formulated pedagogical lessons for students.

\section{Theoretical Framework}

Gardner's theory of multiple intelligences (2011) was the main source driving the research. Gardner's (2011) work with multiple intelligences (MI) has given academia a different perspective on intellectual ability. Gardner (2011) alleges human learning is a combination of capabilities and skills, and these factors can be used to help determine a person's strengths, weaknesses, and personality. Gardner's early work was focused around six different areas of intelligences, but later he expanded those six intelligences into nine distinct areas, verbal-linguistic, logical-mathematical, spatial-visual, bodily-kinesthetic, musical, interpersonal, intrapersonal, naturalist, and existential intelligences.

Other researchers such as Kagan and Kagan (2014) outline two additional intelligences known as naturalist and existential intelligence. In alignment with MI and Gardner's work, Kagan and Kagan (2014) have their own beliefs about human learning. Teachers use visions, a way to improve their teaching methods and the ways students learn (Kagan \& Kagan, 2014). In addition, vision describes what a classroom should look like and bridges the gap between the lessons teachers are teaching and students' comprehension of the material (Kagan \& Kagan, 2014).

The visions identified by Kagan and Kagan (2014) are matching, stretching, and celebrating. Matching consists of determining a student's individual learning style and then matching the teaching style to the student's individual strengths. Stretching gives the teachers opportunity to increase the learning capacity and preferred learning styles of each student. Reaching to the student's outer limits to expand their knowledge base is the goal of the stretching vision. Celebrating is a way for students to achieve success and the way in which teachers measure those accomplishments in the classroom. Teachers are able to easily measure student success with on-the-spot assessments. Celebrating allows teachers to evaluate themselves and see that they can change their teaching methodology without changing the material taught (Kagan \& Kagan, 2014). 
As students learn, they reveal their strengths, weaknesses, and personalities (Kagan \& Kagan, 2014). Students and teachers consider the discoveries of strengths, weaknesses, and personalities to be small academic achievements resulting in more positive attitudes in the classroom overall (Gardner, 2011; Kagan \& Kagan, 2014). According to Daniels (2004), Kagan's theory promotes both teacher and student engagement by interacting with each other regularly. Ultimately, these interactions may increase the chances of higher student success in the classroom (Kagan \& Kagan, 2014). All students learn differently; therefore, teachers need to create environments of freedom and creativity to allow each student to choose the learning style that works best for that student (Daniels, 2004; Gardner, 2011; Kagan \& Kagan, 2014). The emphasis is no longer one of what the teacher teaches, but how the teacher teaches the lesson (Daniels, 2004).

\section{Methods}

This study used an action-based research design including components of both qualitative and quantitative research (Hendricks, 2017; Herr \& Anderson, 2015).The choice of action-based research was appropriate for this study making the study a process for self-reflection (Herr \& Anderson, 2015; Sagor, 2011). Action research is a process completed by the person participating in the action itself and is used when the participant wishes to improve or modify his or her actions in a particular setting (Hendricks, 2017; Sagor, 2011). Herr and Anderson (2015) note that action-based research may require the researcher to be both an internal and external component to the study. Prior to the study, the researcher participates in an external role only, then works both internally and externally after the study begins (Herr \& Anderson, 2015).

Hendricks (2017) reports that internal research can be controlled by the participant while external research is often beyond the control of the participant. In action-based research, internal research questions are often those the participant asks to gain valuable knowledge on how to do things better in the classroom (Herr \& Anderson, 2015). As the researcher and participant in the study, any question able to be directly affected by the researcher-participant becomes internal research (Herr \& Anderson, 2015). According to Hendricks (2017), both quantitative and qualitative research can be considered as either internal or external research depending on the context in which the research question is asked. It was important to utilize both types of research to add validity and credibility to the study (Hendricks, 2017; Herr \& Anderson, 2015).

The study included two different class sections one using flipped learning and the other traditional teaching methodologies. The researcher selected two sections of the same course in a postsecondary, CTE culinary arts program, which created the sample. Each section contained 12 participants. IRB approval was obtained through the researcher's institution. Additional approval was necessary due to the presence in the classes of minors from a dual-enrollment program. The study was therefore also approved by school district administration. The researcher then acquired permission from parents and legal guardians prior to inviting minor students to participate in the study. After all parental consent forms were signed and collected, the students were consented. All invited students signed the consent forms and agreed to participate in the study. 
The data collection instruments were created by the researcher specifically for this study. The first instrument was an engagement matrix which allowed the researcher to consistently and fairly measure student engagement utilizing two different teaching styles, i.e., the flipped classroom and traditional classroom. The matrix measured multiple areas of student engagement, assigning numerical values to each predictor. Five areas of engagement were measured in the matrix: in-class participation, student engagement with instructor, peer engagement, student attentiveness, and student preparedness. At quarterly increments during the semester, the instructor used the engagement matrix to record levels of engagement for all students. Each student was scored individually and given a score ranging from one to four (one, needs direction; two, below expectations; three, meets expectations; and four, exceeds expectations) on each area of engagements. The scores of all students were then averaged to obtain a mean score for each category on the engagement matrix.

The second instrument was the engagement journal, which allowed the researcher to reflect on the same questions at the end of each four-week scoring period. In this engagement journal, the researcher responded to the following questions: how much students are engaged overall, what has the teacher been doing in class today, what are the students working on, and general thoughts for the day.

\section{Researcher Reliability}

Reliability of data collection in action research requires a conscious effort to remain objective (Hendricks, 2017; Herr \& Anderson, 2015: Sagor, 2011). The researcher in this study strived to remain unbiased and objective throughout, regardless of playing a dual role as a participant. In order to support the data collection process and strengthen the findings, the researcher consulted with an educational research professional and reviewed the collected data each week during the study to further ensure objectivity, which is referred to as peer debriefing (Hendricks, 2017). The researcher employed the use of member checks where the researcher periodically discusses results with members of both study groups (Hendricks, 2017). Triangulation of multiple data points was utilized as another method of adding credibility and remaining unbiased in the study (Hendricks, 2017; Sagor, 2011). Additionally, the data collection tools were piloted with other instructors to further test validity and reliability (Creswell, 2014).

\section{Results}

Research Question One. How does the level of engagement differ for students in a traditional culinary arts CTE classroom, as compared to students in a flipped culinary arts CTE classroom? Data for this research question were gathered every four weeks in the semester. The engagement matrix and the engagement journal instrumentation tools were used by the researcher to gather data to answer research question one.

Engagement matrix. Scoring Period One. The first scoring period, week four, resulted in an average engagement score of 2.6 for the flipped classroom and a slightly 
lower score of 2.31 for the traditional classroom. As a whole, neither the flipped nor the traditional class scored a three or four on engagement. A score of three would have indicated that the researcher perceived that student engagement was meeting expectation. A score of four would have indicated students were exceeding expectations. Minimal differences existed in teacher ratings between the two methodologies. The scores obtained from the instructor evaluation from week four are shown in Table 1.

Overall, teacher ratings of the students in the flipped classroom were higher in inclass participation, student engagement with instructor, student attentiveness and student preparedness. Alternatively, the traditional classroom ranked higher in peer engagement than the flipped classroom. At this time, the difference in overall engagement between the two classrooms appeared to be very small; therefore, a proper determination whether the flipped classroom was more engaged could not be made during the beginning weeks of implementation. The results are further reported using a line graph to allow a clear view of the differences and similarities between the classes. (Figure 1).

Scoring Period Two. The researcher observed the students again in week eight, using the engagement matrix to score the level of engagement. In the four weeks since the first observation of engagement, the overall engagement score increased in the flipped classroom by .20, whereas the overall score in the traditional classroom declined by .13 . The scores of each predictor, as observed by the researcher, are shown in Table 2.

Although students in the flipped classroom continued the trend of being more engaged overall, both the flipped classroom and the traditional classroom experienced a decline in the predictor of in-class participation from the previous observation in week four. Both class formats increased in scores for student engagement with the instructor in the second quarter, but this time, the flipped classroom scored lower than the traditional classroom. Peer engagement remained consistent for the traditional classroom, as well as scoring higher than the flipped classroom; however, the flipped classroom did show an increase in peer engagement.

In the remaining two predictors for week eight, student attentiveness and student preparedness, the flipped classroom experienced an increase, while the traditional classroom experienced a decrease. The first three predictors (in-class participation, student engagement with instructor, and peer engagement) remained relatively consistent with week four, during the week eight observation period. Comparatively, the last two predictors, student attentiveness and student preparedness, began to show a wider margin of difference in measured engagement. The information for week eight in a line graph depicting the plotted results for the scores is illustrated in Figure 2.

Although week eight data reflected consistency in the flipped classroom having higher levels of engagement when compared to the traditional classroom in student engagement; overall, it was only an increase of .20 from the previous measurement in week four. Compared to week four, the flipped classroom achieved engagement scores near or higher than the meeting expectations score of 3.0. However, engagement scores from the traditional classroom still fell below this mark. Figure 2. is a visual presentation of the increasing engagement gap between the two classrooms. 
Table 1. Week Four Engagement Data

$\begin{array}{lllll}\text { In-Class } & \text { Student } \& & \text { Peer } & \text { Student } & \text { Student }\end{array}$

Participation Instructor Engagement Attentiveness Preparedness $M$

$\begin{array}{lllllll}\text { Flip. }^{\text {a }} & 2.85 & 2.62 & 2.15 & 2.69 & 2.69 & 2.60\end{array}$

$\begin{array}{lllllll}\text { Trad. }^{\text {b }} & 2.44 & 2.56 & 2.33 & 2.22 & 2.00 & 2.31\end{array}$

Note. $M=$ Mean Score Total Student Engagement Week Four. ${ }^{\mathrm{a}}$ Flipped Classroom. ${ }^{\mathrm{b}}$ Traditional Classroom. A score of 3 is considered meeting expectations.

Figure 1

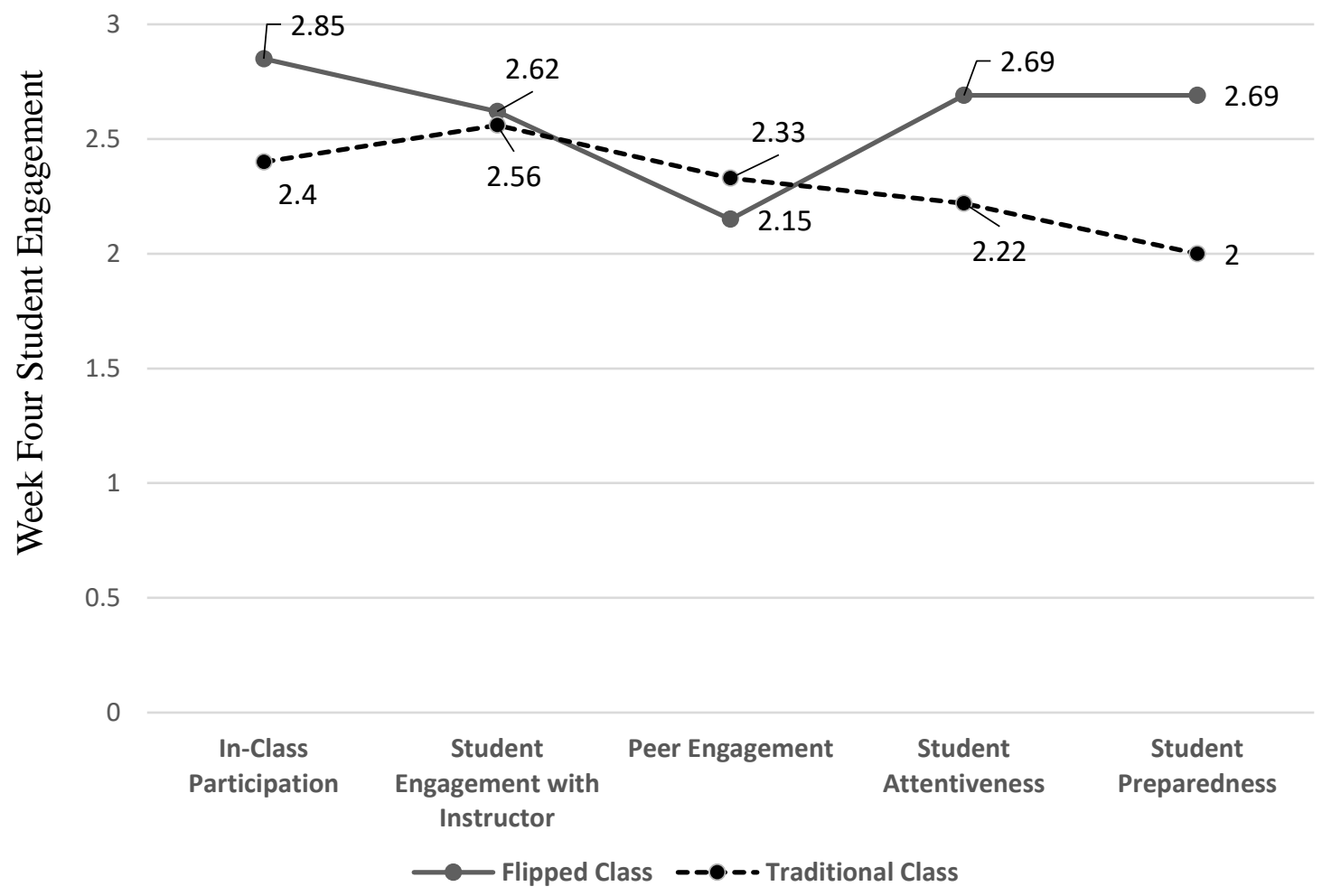

Figure 1. Student engagement results week four. Points represent each predicator being measured for student engagement in week four. 
Table 2. Week Eight Engagement Data

\begin{tabular}{|c|c|c|c|c|c|c|}
\hline & $\begin{array}{c}\text { In-Class } \\
\text { Participation }\end{array}$ & $\begin{array}{l}\text { Student \& } \\
\text { Instructor }\end{array}$ & $\begin{array}{c}\text { Peer } \\
\text { Engagement }\end{array}$ & $\begin{array}{c}\text { Student } \\
\text { Attentiveness }\end{array}$ & $\begin{array}{c}\text { Student } \\
\text { Preparedness }\end{array}$ & $M$ \\
\hline Flip. $^{\mathrm{a}}$ & 2.62 & 2.77 & 2.31 & 3.38 & 2.92 & 2.80 \\
\hline Trad. b & 2.22 & 2.89 & 2.33 & 2.00 & 1.44 & 2.18 \\
\hline
\end{tabular}

Note. $M=$ Mean Score Total Student Engagement Week Eight. ${ }^{\mathrm{a}}$ Flipped Classroom. ${ }^{\mathrm{b}}$

Traditional Classroom. A score of 3 is considered meeting expectations.

Figure 2

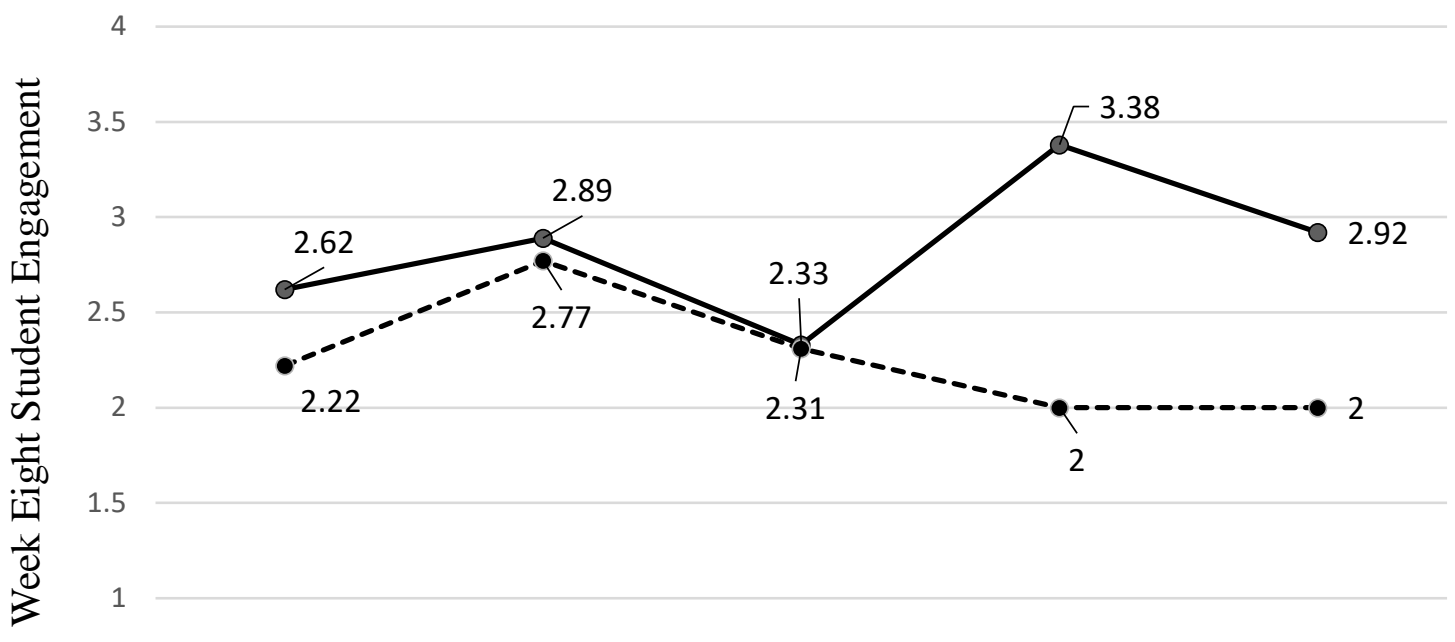

0.5

0

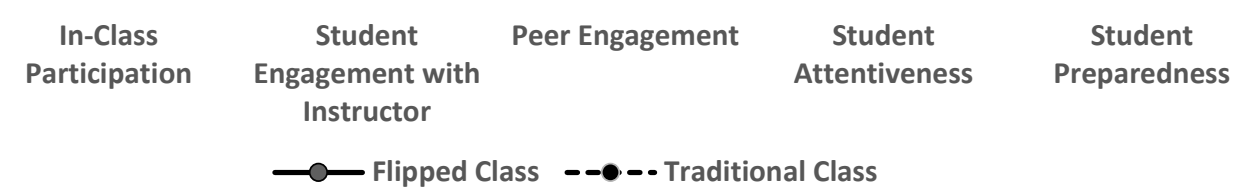

Figure 2. Student engagement results week eight. Points represent each predicator being measured for student engagement in week eight. 
Scoring Period Three. In week 12, the gap in engagement between the flipped classroom and the traditional classroom continued to widen. Both classroom formats displayed growth in overall engagement; however, the flipped classroom continued the pattern of being more engaged according to the engagement matrix. The flipped classroom experienced a mean increase of .43, compared to a .27 increase in the traditional classroom, further increasing the cumulative mean of 2.88 for the flipped classroom and 2.31 for the traditional classroom. The data recorded by the researcher in week 12 are presented in Table 3.

In-class participation showed nearly a one-point growth for the flipped classroom, compared to the traditional classroom, which only experienced slightly over .50 in growth. Like week eight, the flipped classroom encountered growth in student engagement with the instructor, while the traditional classroom experienced a decline from previous measurements in week eight. Week 12 was also the first week in the data collection period when the flipped classroom performed higher in all predictors than the traditional classroom. (Figure 3).

Since the data collection period during week eight, peer engagement increased in the flipped classroom and decreased in the traditional classroom, reporting a difference of .90 between the two teaching styles. During week 12, the flipped classroom met expectations in all predictors by scoring a three or above, except in student preparedness. The traditional classroom failed to meet expectations in all engagement predictors. Although the flipped classroom had a decrease in student preparedness from week eight, the flipped classroom was more engaged than the traditional classroom. By the end of the week 12, the overall engagement scores for the flipped classroom continued to show an increase from week eight, increasing from 2.80 to 3.23. Likewise, the traditional classroom increased from week eight, growing from 2.18 to 2.45 .

Scoring Period Four. During week 16, the final week of the semester, students were observed and evaluated over the same predictors as in weeks four, eight, and twelve. The data recorded in week 16 reflected a greater difference in instructor recorded engagement scores between the flipped classroom and the traditional classroom. While the average engagement score for the flipped classroom was 3.29, the traditional classroom was only 2.65, resulting in the flipped classroom being rated higher in the areas measured for engagement than the traditional classroom. The flipped classroom experienced a decrease for the predictor of in-class participation from week 12. A slight gain of .13 was recorded for in-class participation for the traditional classroom.

Both the flipped and traditional classroom showed growth in student engagement with the instructor, with the flipped classroom still scoring higher than the traditional classroom. Peer engagement was also an area both the flipped and traditional classrooms showed growth. The flipped classroom showed progress in growth of engagement of .23. The traditional classroom had a gain of .50. Even with higher gains, the traditional classroom still scored lower in engagement compared to the flipped classroom. The traditional classroom scored below a three indicating it was not meeting expectations. The scored predictors for week 16 are presented in Table 4. 
Table 3. Week Twelve Engagement Data

\begin{tabular}{ccccccc} 
& $\begin{array}{c}\text { In-Class } \\
\text { Participation }\end{array}$ & $\begin{array}{c}\text { Student \& } \\
\text { Instructor }\end{array}$ & $\begin{array}{c}\text { Peer } \\
\text { Engagement }\end{array}$ & $\begin{array}{c}\text { Student } \\
\text { Attentiveness }\end{array}$ & $\begin{array}{c}\text { Student } \\
\text { Preparedness }\end{array}$ & $M$ \\
\hline Flip. $^{\text {a }}$ & 3.46 & 3.31 & 3.15 & 3.38 & 2.85 & 3.23 \\
Trad. $^{\text {b }}$ & 2.75 & 2.5 & 2.25 & 2.25 & 2.5 & 2.45 \\
\hline
\end{tabular}

Note. $M=$ Mean Score Total Student Engagement Week Twelve. ${ }^{\mathrm{a}}$ Flipped Classroom. ${ }^{\mathrm{b}}$ Traditional Classroom. A score of 3 is considered meeting expectations.

Figure 3

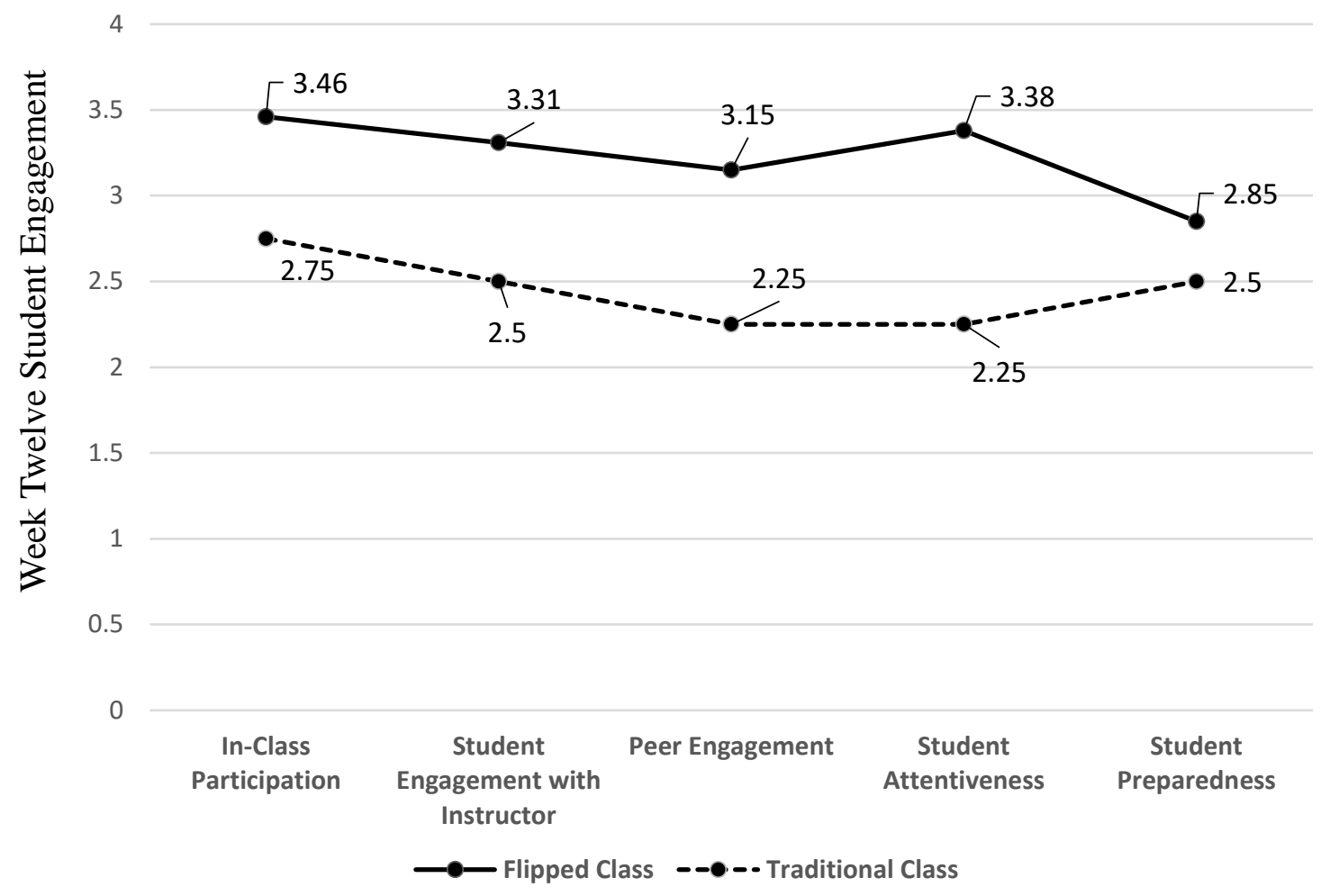

Figure 3. Student engagement results week 12. Points represent each predicator being measured for student engagement in week 12. 
The instructor measured and compared student attentiveness, resulting in a score of 3.23 for the flipped classroom and a score of 2.38 in the traditional classroom. Student preparedness was the last item to be measured by the researcher, and a different result was obtained. The traditional classroom remained consistent with the week 12 score of 2.5 student preparedness, but the flipped classroom experienced growth of .23 in student preparedness, resulting in a score of 3.08. Both teaching strategies encountered growth in student engagement from the beginning of the semester to the end, but the traditional classroom never reached an overall score of 3.0 or higher. (Figure 4).

Overall Scoring Period Analysis. Comparing the beginning of the semester in week four to the end of the semester in week 16, the scoring for both the flipped classroom and the traditional classroom showed different patterns of engagement. In week four, the scores for each classroom showed less of a gap between the engagement scores, whereas in week 16, the scores between the two classrooms continued to widen and depict a difference in how the instructor rated the different areas of engagement. The classes seemed to taper off in the levels of engagement, meaning the scores obtained by students in each classroom remained relatively consistent. The data for week 16 is illustrated in Table 5.

The scores for each area of engagement for the entire 16 weeks were averaged together to obtain a mean score. The scores are displayed in Table 5. Overall, half of the scores for the flipped classroom reached a three or above which is indicative of meeting expectations on the matrix. Two areas, peer engagement and student preparation were still below the score of three. The traditional classroom while making progress in most of the areas, was below a score of three in all the areas measured on the matrix.

Overall data from the 16-week semester reflected gains of .58 for the flipped classroom in peer engagement and growth of .62 in peer engagement for the traditional classroom. Peer engagement increased for the flipped classroom, averaging 2.73, with 2.33 for the traditional classroom, which showed no signs of increase from weeks four or eight. Both the flipped classroom and traditional classroom experienced consistent amounts of growth in student preparedness, with a .20 increase in the flipped classroom and .25 in the traditional. Overall, the median for the flipped classroom was 3.00, which was only a slight growth of .41 since the fourth week measurement. The traditional classroom resulted in 2.41, which increased only .10 from week four. The median scores are displayed in Figure 5.

Engagement journal. The second instrument used to record engagement data was the engagement journal, in which the researcher reflected every four weeks throughout the semester, at the end of each scoring period. The same questions were answered each scoring period: how much students are engaged overall, what has the teacher been doing in class today, what are the students working on, and general thoughts for the day. To add a quantifiable way to record engagement data, a Likert scale was added to the first question regarding overall student engagement. The scale included needs additional direction, below expectations, meets expectations, and exceeds expectations. The data from the remaining questions was analyzed using a content analysis to synthesize themes. 
Table 4. Week Sixteen Engagement Data

\begin{tabular}{lcccccc}
\hline & $\begin{array}{c}\text { In-Class } \\
\text { Participation }\end{array}$ & $\begin{array}{c}\text { Student \& } \\
\text { Instructor }\end{array}$ & $\begin{array}{c}\text { Peer } \\
\text { Engagement }\end{array}$ & $\begin{array}{c}\text { Student } \\
\text { Attentiveness }\end{array}$ & $\begin{array}{c}\text { Student } \\
\text { Preparedness }\end{array}$ & $M$ \\
\hline Flip. $^{\text {a }}$ & 3.31 & 3.46 & 3.38 & 3.23 & 3.08 & 3.29 \\
Trad. $^{\text {b }}$ & 2.88 & 2.75 & 2.75 & 2.38 & 2.5 & 2.65 \\
\hline $\begin{array}{l}\text { Note. } M=\text { Mean Score Total Student Engagement Week 16. } \\
\text { Classroom. A } \text { F score of 3 is considered meeting expectations. }\end{array}$
\end{tabular}

Figure 4

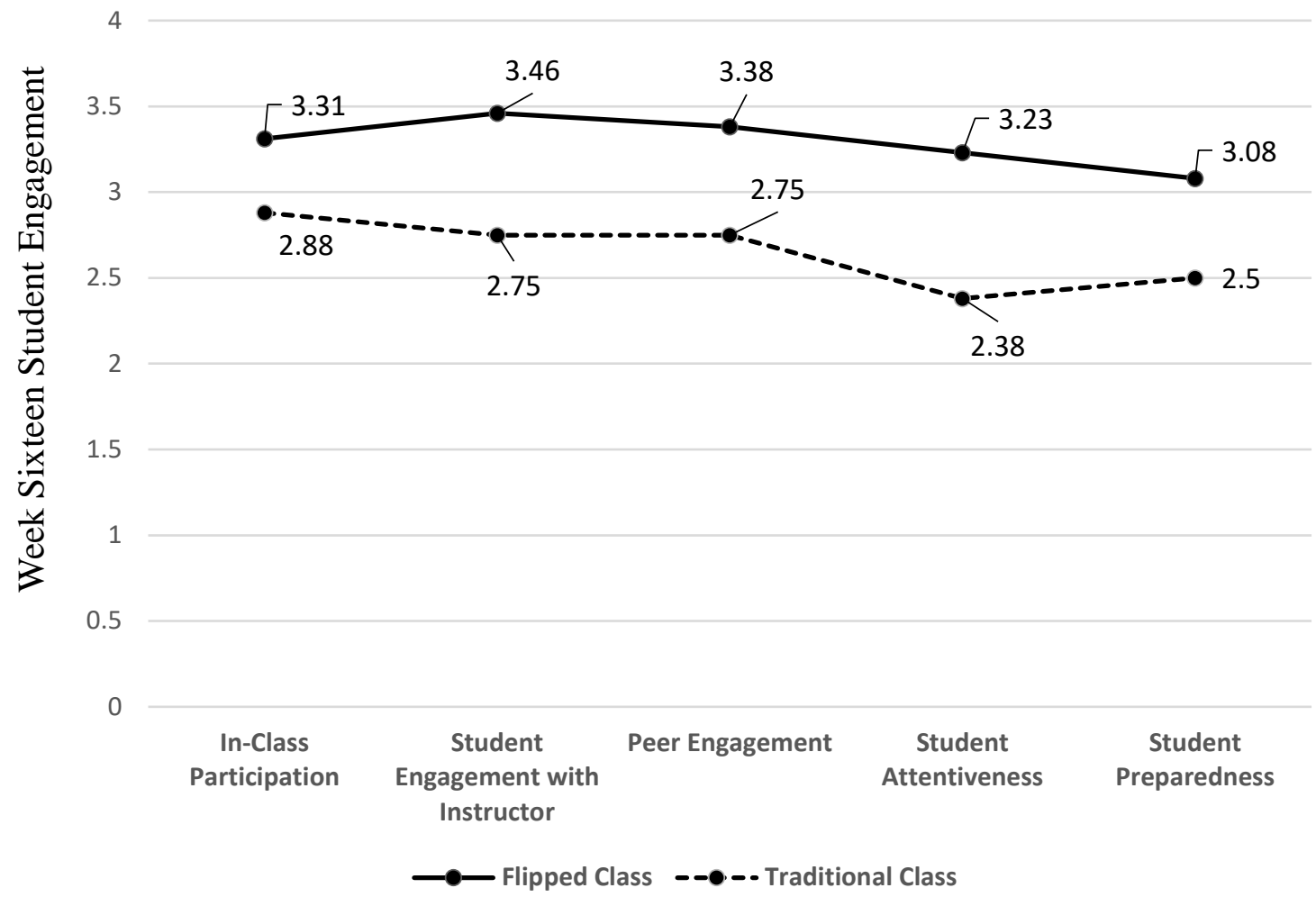

Figure 4. Student engagement results week 16. Points represent each predicator being measured for student engagement in week 16. 
Table 5. Student Engagement Data for all Sixteen Weeks

\begin{tabular}{lcccccc}
\hline & $\begin{array}{c}\text { In-Class } \\
\text { Participation }\end{array}$ & $\begin{array}{c}\text { Student \& } \\
\text { Instructor }\end{array}$ & $\begin{array}{c}\text { Peer } \\
\text { Engagement }\end{array}$ & $\begin{array}{c}\text { Student } \\
\text { Attentiveness }\end{array}$ & $\begin{array}{c}\text { Student } \\
\text { Preparedness }\end{array}$ & $M$ \\
\hline Flip. $^{\text {a }}$ & 3.06 & 3.04 & 2.75 & 3.17 & 2.89 & 2.98 \\
Trad. $^{\text {b }}$ & 2.57 & 2.68 & 2.42 & 2.21 & 2.11 & 2.40 \\
\hline
\end{tabular}

Note. $M=$ Mean Score Median Engagement Data for all 16 Weeks. ${ }^{\text {a }}$ Flipped Classroom. ${ }^{\mathrm{b}}$ Traditional Classroom. A score of 3 is considered meeting expectations.

Figure 5

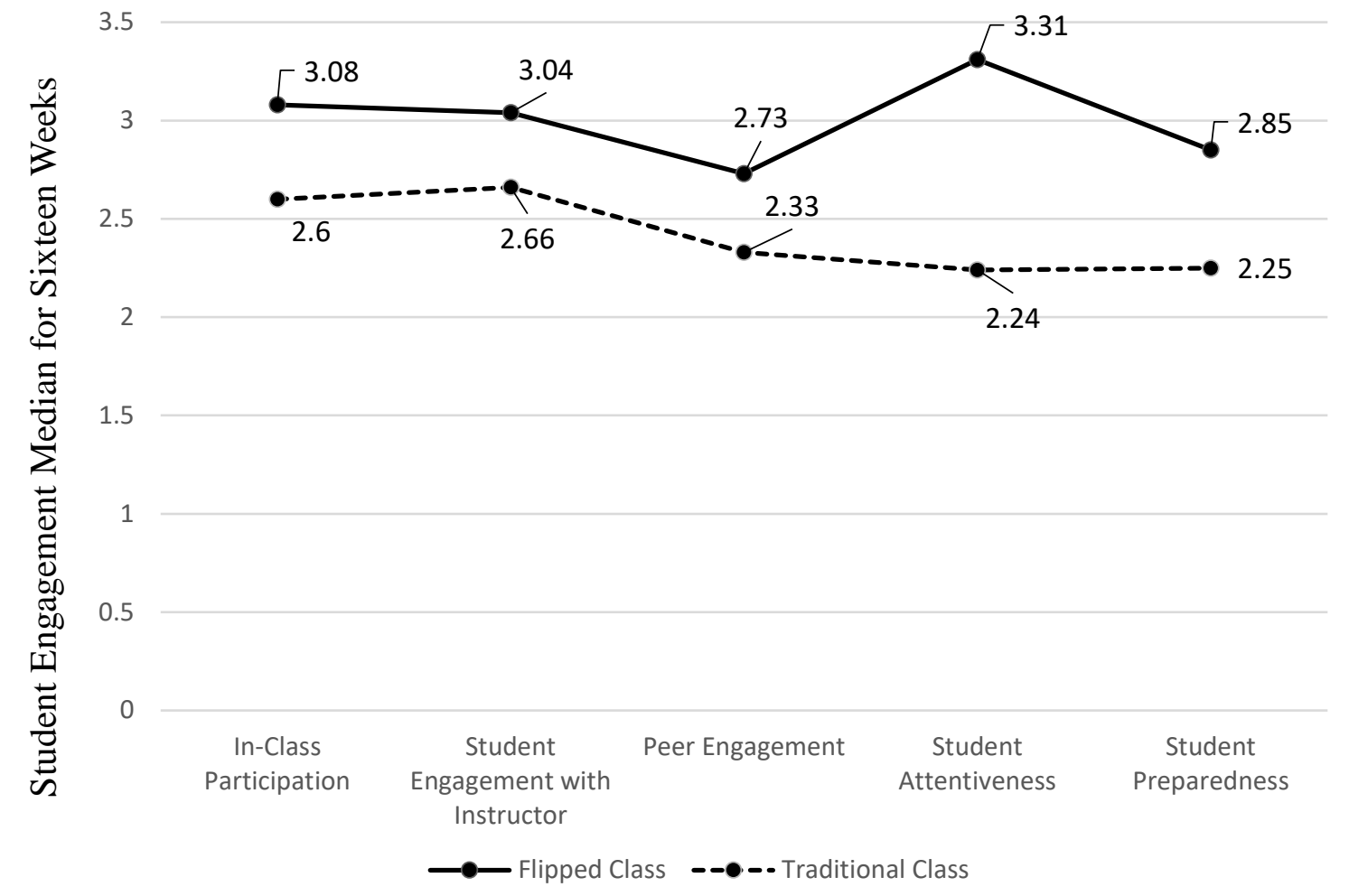

Figure 5. Student engagement for 16 weeks. Points represent each predicator being measured for student engagement throughout the 16-week period. 
The flipped classroom met expectations in weeks four and twelve and exceeded expectations in weeks eight and sixteen. Comparatively, the traditional classroom fell below expectations all four weeks when engagement was measured and evaluated. Based on instructor observations as the researcher, the difference between the levels of engagement for the flipped classroom and the traditional classroom was group dynamics.

The students in the flipped classroom seemed eager to get involved with their learning by taking ownership and working collaboratively together. Students who were struggling were supported, encouraged, and coached by students in the class. In the traditional classroom, the group dynamic appeared to be the opposite. According to the ratings given by the instructor, students did not score well in areas that would be indicative of building classroom community, did not work well as a cohesive group, and were not willing to encourage or support peers who were struggling.

What has the teacher been doing in class today? During the 16-week semester, the instructor was able to become a facilitator of information, coach, guide, and a cheerleader. No longer was the role of the instructor someone who stood in front of the students attempting to teach concepts, while keeping the students entertained, engaged, focused, and awake. By delivering all the content to the students through the pre-recorded digital video lessons outside of class, the time in class was spent by the instructor working with students individually and in groups. The flipped classroom teaching methodology allowed instructor-student conferences on a daily, weekly, or monthly basis depending on the need.

Flexibility was built into the flipped classroom schedule, which was not something the traditional classroom was able to do. If students in the flipped classroom were struggling with concepts, more time during class was available to address those concerns, because the material had been presented prior to class. In the traditional classroom, the content was covered during the class period, so there was limited time to support students who did not master the content.

Arrangements outside of the classroom needed to be made to support additional learning for the students who had not mastered the content. The instructor was also able to use the flexibility of the flipped classroom to identify students who were struggling with mastering concepts and work with them immediately, without disrupting or delaying other students. Rather than moving on and leaving some students behind, the format of the flipped classroom allowed all students an equal education opportunity. Comparatively, the students who were struggling with concepts in the traditional classroom were left behind, because the group moved together whether all students had mastered concepts or not.

In the flipped classroom, the instructor was able to get to know all the students much better individually, but most importantly the students who were struggling. After identifying the students who were struggling, the instructor was able to spend quality time with each student to determine the best learning environments and teaching strategies to benefit the individual student. Not only did this time benefit students' grades, it also helped strengthen students' confidence and their abilities to perform well in class and interact more with other students.

What are the students working on? In the flipped classroom, students spent their time working independently and in groups of varying sizes ranging from two students to the entire class, creating a student-centered learning environment. Meanwhile, the students 
in the traditional classroom spent each day in a teacher-centered environment, listening to lecture and taking notes. On a typical day in the flipped classroom, students would begin their day by taking a content quiz over previous night's digital video lesson. Students who did well on the quiz and had viewed the lessons prior to class would move on with their inclass activity folder. Students who did not perform to standards on the quiz or had not viewed the digital video lessons prior to class would be required to watch the lesson before moving onto their next in-class activity.

In the flipped classroom, students would complete homework assignments, quizzes, exams, and varying related learning activities, which further expanded the content of the digital lessons. Students were able to get immediate help and guidance from the instructor when they needed it, rather than waiting until the next day. Because of the digital format of the lessons in the flipped classroom, if students did not complete the activities of the day, they were able to pick up where they left off the following day of class. Students were able to research and master concepts before moving into the lab to apply the concepts, thereby doing better in the hands-on application.

Students in the traditional classroom listened to lectures and only completed quizzes and exams during class time. The traditional methodology did not allow time during class to complete all coursework, which made students responsible for completing assignments outside of class, often resulting in students not fully comprehending the material presented before it was necessary to move on with the course curriculum. The lack of completion of all necessary assignments often led to lower grades in the traditional classroom.

In the flipped classroom, students were able to move forward learning concepts on exam days once they were finished with their exam, because they already knew which activities to complete next, whereas the students in the traditional classroom had to wait for lecture. Comparatively, the students in the traditional classroom had to wait for their peers to complete their exams before moving on as a group, and if additional time was needed to master a concept, alternative times had to be scheduled. Comparing these two classroom structures in this manner gave both the instructor and students the opportunity to see exactly how much time is lost in the traditional classroom merely waiting, compared to the flipped classroom, where no time is wasted since students already have assigned tasks they can move onto next.

General thoughts for the day. This 16-week study of the flipped classroom was quite informative. The class went smoothly and was fulfilling to see how much time was spent one-on-one between the instructor and students. Even dedicating time to each individual student throughout the class, the instructor still found it easy to remain attentive to the remaining class's needs. Additionally, it was noted how much outside class learning the flipped classroom created, since students knew they would have an assessment when arriving to class. The flipped classroom allowed students to move onto other activities, without waiting for the entire class to finish one activity before moving to the next, therefore mitigating the loss of productive class time.

In the traditional class, the students did not prepare well for the daily assessments, which could possibly be an indicator of the lack of outside class learning which took place, even though students were provided the same tools as the flipped classroom. The students 
in general seemed to present a normal attitude, coming to the traditional class underprepared. As the participant in the data collection, it was interesting to see how limiting the traditional class methodology can be. Students were unable to move forward until all students had completed the activity; therefore, it was alarming to see just how ineffective this classroom structure is and how much time was lost in class.

Research Question Two. What differences exist, if any, in student academic performance in a traditional culinary arts technical education classroom, as compared to students in a flipped culinary arts technical education classroom, as measured by end of course grades? For this piece of data collection, the de-identified, end of semester grades were analyzed using statistical analysis. Specifically, a two-tailed $t$-test was used (Bluman, 2009).

The mean score for end of course grades for the flipped classroom was 80.90. For the traditional classroom, the mean score for end of course grades was 77 . In order to be considered significant, a $P$-value score of .05 or less needed to be obtained. After analysis, the $P$-value was found to be 0.3771 , which is greater than .05 . Thus, there was not sufficient evidence to indicate a significant difference between the end of course grades for the flipped classroom and the traditional classroom.

\section{Discussion}

Engagement varied between each teaching modality. Overall, students who participated in the flipped classroom seemed to score higher, on average, than the students in the traditional classroom (Tune et al., 2013). The level of student engagement and inclass participation with each other and the instructor were also higher in the flipped classroom than the traditional classroom. These findings were similar from those of Evseeva and Solozhenko (2015). In most weeks, students prepared more in the flipped classroom by watching the digital video lessons knowing they would have a mastery quiz upon arrival to the class the next day (Fulton, 2012a; Hamdan, McKnight, McKnight, \& Arfstrom, 2013).

Although not statistically significant, the grades in the flipped classroom were nearly 4\% higher than those in the traditional classroom. Hamdan et al. (2013) and Brame (2013) also note students reported higher grades during and at the end of semesters. Allowing the students to utilize technology in the classroom throughout the study also had a positive effect on their grades, which is similar to Brame’s (2013) findings.

After reflecting on this study, the success of flipped learning ensures the traditional classroom is not recreated by merely adding technology. Providing access to the content is vital to the success of the flipped classroom (Bergmann \& Sams, 2012); however, student engagement also needs to be addressed to ensure students will want to actively learn and excel academically (Fulton, 2012c; Kim et. al., 2014). Teachers should make the videos as fun and interactive as possible to avoid just recreating a classroom lecture on video (Pearson, 2014).

In the ideal flipped classroom setting with a lab component such as the one in this study, it would be beneficial to have free access to both lecture and lab rooms, as well as 
instructor availability. The level of student engagement and academics could significantly increase by using both components simultaneously. Ideally, students who prepared properly for class would advance to lab upon passing their chapter comprehension quiz at the beginning of class, as they have displayed mastery of the content (Cargile \& Harkness, 2015). Students who did not pass the written requirements would stay in the lecture room, re-watch the digital video lessons, and work on supplemental in-class activities to help comprehension of the content to master their quiz, then advance into the lab. Perhaps if students knew they would directly go to lab after mastering their quiz, more students would do a better job preparing so they could progress to the more engaging, "fun" component of the class at a quicker rate.

Although overall grades were monitored throughout the entire study, more meaningful data could have been collected by monitoring the homework completion percentage on a weekly basis between the flipped classroom and traditional classroom. Monitoring and recording these data could provide more support and validity to the effectiveness or ineffectiveness of the flipped classroom. Measuring the amount of completed homework in both flipped and traditional classrooms could also disseminate data on the level of student engagement and preparedness. Another approach would be to focus on the lecture portion of the flipped classroom grades, instead of students' combined lecture and lab grades. In these particular culinary arts lab classes, students' grades are characteristically based off overall performance. Since the grade average is typically higher in the lab component, it moderately skews the outcome of the true measure of the effectiveness of the flipped classroom as an independent variable. Although part of the study was measuring performance in the lab based off how well the flipped classroom prepared the students compared to the traditional classroom, merely looking at the scores only from non-lab days would create a larger gap in scores between the two teaching methodologies.

\section{Recommendations for Future Research}

There are several ways this study can serve as a springboard for future research. A future study may be conducted by taking the data obtained from measuring levels of student engagement and running statistical analysis on those data. In addition, finding additional ways to objectively measure in-class participation could provide more data to determine the effectiveness of the flipped classroom.

Separating hands-on lab activities and seated-classroom activities may provide more specific statistical evidence of success of the flipped classroom, since in this study, those activities were not differentiated. Further disaggregation, such as looking at grades on exams separately from assignment and activity grades, may also provide more evidence of the effectiveness of the flipped classroom when compared to the traditional classroom. Using different research methodologies, such as quantitative, qualitative and mixed methods research would produce multi-faceted data which could then be used to view the flipped classroom format holistically. 


\section{References}

Bergmann, J., \& Sams, A. (2012). How the flipped classroom is radically transforming learning. Retrieved from http://www.thedailyriff.com/articles/how-the-flipped-classroom-isradically-transforming-learning-536.php.

Bergmann, J., \& Sams, A. (2013). Flip your students' learning. Educational Leadership, 70(6),16-20.

Bergmann, J., \& Sams, A. (2014). Flipping for mastery. Educational Leadership, 71(4),24-29.

Bergmann, J., Overmyer, J., \& Wilie, B. (2013). The flipped class: Myths vs. reality. Retrieved from http://www.thedailyriff.com/articles/the-flipped-class-conversation-689.php.

Bluman, A. (2009). Elementary statistics : A brief version. Columbus, OH: McGraw Hill.

Brame, C. (2013). Flipping the classroom. Vanderbilt University Center for Teaching. Retrieved from http://cft.vanderbilt.edu/guides-sub-pages/flipping-the-classroom/

Brunsell, E., \& Horejsi, M. (2013). Flipping your classroom in one take. The Science Teacher, 80(3), 8.

Burgoyne, S., \& Eaton, J. (2018). The partially flipped classroom: The effects of flipping a module on "junk science" in a large methods course. Teaching of Psychology,45(2), 154157. https://doi.org/10.1177/0098628318762894

Cargile, L., \& Harkness, S. (2015). Flip or flop: Are math teachers using Khan Academy as envisioned by Sal Khan? TechTrends, 59(6), 21-27. https://doi.org/10.1007/s11528-0150900-8

Carter, C., Carter, R., \& Foss, A. (2018). The flipped classroom in a terminal college mathematics course for liberal arts students. AERA Open, 4(1), 1-14. https://doi.org/10.1177/2332858418759266

Castedo, R., Lopen, L., Chiquito, M., Navarro, J., Cabrera, J., \& Ortega, M. (2019). Flipped classroom comparative case study in engineering in higher education. Computer Applications in Engineering Education, 27(1), 206-211. https://doi.org/10.1002/cae.22069

Chapman, A. (2014). Howard Gardner's multiple intelligences. Retrieved from http://www.businessballs.com/howardgardnermultipleintelligences.htm

Creswell, J. (2014). Research design qualitative, quantitative, and mixed methods approaches. Thousand Oaks, CA: SAGE Publications.

Daniels, P. (2004). An overview of Gardner's multiple intelligences, Kagan's structures and Tomlinson's differentiated instruction and their correlation to Nunley's layered curriculum. Retrieved from http://help4teachers.com/PatPaper.htm

DeGennaro, D. (2008). Learning designs: An analysis of youth-initiated technology use. Journal of Research on Technology in Education, 41(1), 1-20. https://doi.org/10.1080/15391523.2008.10782520

Enfield, J. (2013). Looking at the impact of the flipped classroom model of instruction on undergraduate multimedia students at CSUN. TechTrends 57(6), 14-28. https://doi.org/10.1007/s11528-013-0698-1

Estes, M., Ingram, R., \& Liu, C. (2014). A review of flipped classroom research, practice, and technologies. International HETL Review, 4(7). Retrieved from https://www.hetl.org/feature-articles/a-review-of-flipped-classrom-research-practice-andtechnologies

Evseeva, A., \& Solozhenko, A. (2015). Use of flipped classroom technology in language learning. Procedia Social and Behavioral Sciences, 205-209. https://doi.org/10.1016/j.sbspro.2015.10.006 
Fickes, M. (2014). Flipping technology. School Planning and Management. Retrieved from https://webspm.com/articles/2014/11/01/flipped-classroom.

Flumerfelt, S., \& Green, G. (2013). Using lean in the flipped classroom for at risk students. Educational Technology \& Society, 16(1), 356-366.

Foster, G., \& Stagl, S. (2018). Design, implementation, and evaluation of an inverted (flipped) classroom model economics for sustainable education course. Journal of Cleaner Production, 183, 1323-1336. https://doi.org/10.1016/j.jclepro.2018.02.177

Fulton, K. (2012a). Inside the flipped classroom. Retrieved from http://thejournal.com/Articles/2012/04/11/The-flipped-classroom

Fulton, K. (2012b). Upside down and inside out: Flip your classroom to improve student learning. Learning \& Leading with Technology, June/July, 13-17.

Fulton, K. (2012c). 10 reasons to flip. Phi Delta Kappan, 94(2), 20-24. https://doi.org/10.1177/003172171209400205

Gardner, H. (2011). Frames of mind: The theory of multiple intelligences. New York, NY: Basic Books Inc.

Goodwin, B., \& Miller, K. (2013). Research says evidence on flipped classrooms is still coming in. Educational Leadership, 70(6), 78-80. Retrieved from http://www.ascd.org/publications/educational-leadership/mar13/vol70/num06/Evidenceon-Flipped-Classrooms-Is-Still-Coming-In.aspx

Gullen, K., \& Zimmerman, H. (2013). Saving time with technology infusing technology thoughtfully into instruction can free up time for meaningful learning. Educational Leadership, 70(6), 63-66. Retrieved from http://www.ascd.org/publications/educationalleadership/mar13/vol70/num06/Saving-Time-with-Technology.aspx

Hamdan, N., McKnight, P., McKnight, K., \& Arfstrom, K. (2013). A review of flipped learning. Retrieved from http://flippedlearning.org/cms/lib07/VA01923112/Centricity/Domain/41/LitReview_Flip pedLearning.pdf

Hendricks, C. (2017). Improving schools through action research: A reflective practice approach. Upper Saddle River, NJ: Pearson Education Inc.

Herr, K. \& Anderson, G. (2015). The action research dissertation: A guide for students and faculty. Thousand Oaks, CA: SAGE Publications.

Herreid, F., \& Schiller, N. (2013). Case studies and the flipped classroom. Journal of College Science Teaching, 42(5), 62-66.

Hutchings, M., \& Quinney, A. (2015). The flipped classroom, disruptive pedagogies, enabling technologies and wicked problems: Responding to "the bomb in the basement." Electronic Journal of e-Learning, 13(2), 106-119.

Jukes, I., McCain, T., Crockett, L., \& Prensky, M. (2010). Understanding the digital generation: Teaching and learning in the new digital landscape (the 21st century). Vancouver, BC, Canada: Abella Publishing Services.

Kagan, S. \& Kagan, M. (2014). Multiple intelligences structures-opening doors to learning. San Clemente, CA: Kagan Publishing.

Kern, J. (2013). Tips to help you flip your classroom. Education Update, 55(2), 1-5. Retrieved from http://www.ascd.org/publications/newsletters/educationupdate/feb13/vol55/num02/Tips-to-Help-You-Flip-Your-Classroom.aspx

Kim, M., Kim, S., Khera, O., \& Getman, J. (2014). The experience of three flipped classrooms in an urban university: An exploration of design principles. Internet and Higher Education, 22, 37-50. https://doi.org/10.1016/j.iheduc.2014.04.003 
Kovach, J. (2014). Leadership in the “classroom.” The Journal for Quality and Participation, $37(1), 39$.

Leacock, S. (1922). My discovery of England. New York, NY: Dodd, Mead and Company.

Leung, J., Kumta, S., \& Yung, A. (2014). Short review of the flipped classroom approach. Medical Education, 48(11), 1127. https://doi.org/10.1111/medu.12576

Lewis, C., Chen, D., \& Relan, A. (2018). Implementation of a flipped classroom approach to promote active learning in the third-year surgery clerkship. The American Journal of Surgery, 215(2), 298-303. https://doi.org/10.1016/j.amjsurg.2017.08.050

Lo, C. (2018). Grounding the flipped classroom approach in the foundations of educational technology. Educational Technology Research and Development, 66(3), 793-811. https://doi.org/10.1007/s11423-018-9578-x

Love, B., Hodge, A., Grandgenett, N., \& Swift, A. (2014). Student learning and perceptions in a flipped linear algebra course. International Journal of Mathematical Education in Science and Technology, 45(3), 317-324. https://doi.org/10.1080/0020739X.2013.822582

Lujan, H., \& DiCarlo, S. (2014). The flipped exam: Creating an environment in which students discover for themselves the concepts and principles we want them to learn. Advances in Physiology Education, 38, 339-342. https://doi.org/10.1152/advan.00081.2014

MacKinnon, G. (2015). Determining useful tools for the flipped science education classroom. Contemporary Issues in Technology and Teacher Education, 15(1), 44-55. Retrieved from https://www.citejournal.org/volume-15/issue-1-15/science/determining-usefultools-for-the-flipped-science-education-classroom

McCrea, B. (2014). Flipping the classroom for special needs students. The Journal. Retrieved from https://thejournal.com/articles/2014/06/30/flipping-the-classroom-for-special-needsstudents.

Ng, W. (2014). Flipping the science classroom exploring merits, issues and pedagogy. Teaching Science:The Journal of the Australian Science Teachers Association, 60(3), 16-27.

Pearson, G. (2014). Students, parents give thumbs-up to flipped classroom. Education Canada, 54(4).

Pellas, N. (2017). Is the flipped classroom model for all? Correspondence analysis from trainee instructional media designers. Education and Information Technologies, 23(2), 757-775. https://doi.org/10.1007/s10639-017-9634-x

Ryan, M., \& Red, S. (2016). Impact of the flipped classroom on student performance and retention: A parallel controlled study in general chemistry. Journal of Chemical Education, 93(1), 13-23.

Sagor, R. (2011). The action research guidebook: A four-stage process for educators and school teams. Thousand Oaks, CA: Corwin.

Sezer, B. (2017). The effectiveness of a technology-enhanced flipped science classroom. Journal of Educational Computing Research, 55(4), 471-494. https://doi.org/10.1177/0735633116671325

Talbert, R. (2012). Inverted classroom. Education Reform, 9(1), 7. Retrieved from https://scholarworks.gvsu.edu/colleagues/vol9/iss1/7

Tucker, C. (2013). The basics of blended instruction. Educational Leadership, 70(6), 57-60. Retrieved from http://www.ascd.org/publications/educationalleadership/mar13/vol70/num06/The-Basics-of-Blended-Instruction.aspx

Tune, J., Sturek, M., \& Basile, D. (2013). Flipped classroom model improves graduate student performance in cardiovascular, respiratory, and renal physiology. Advances in Physiology Education, 37(4) 316-320. https://doi.org/10.1152/advan.00091.2013 
Ullman, E. (2013). Tips to help you flip your classroom. Educational Leadership, 55(2), 1-5. Retrieved from http://www.ascd.org/publications/newsletters/educationupdate/feb13/vol55/num02/Tips-to-Help-You-Flip-Your-Classroom.aspx 